\title{
Coal Bottom Ash for Portland Cement Production
}

\author{
Cristina Argiz, ${ }^{1}$ Miguel Ángel Sanjuán, ${ }^{2}$ and Esperanza Menéndez ${ }^{3}$ \\ ${ }^{1}$ Civil Engineering School, Polytechnic University of Madrid, C/Profesor Aranguren, s/n, Ciudad Universitaria, 28040 Madrid, Spain \\ ${ }^{2}$ Spanish Institute of Cement and Its Applications (IECA), C/José Abascal 53, 28003 Madrid, Spain \\ ${ }^{3}$ Eduardo Torroja Institute for Construction Science, CSIC, C/Serrano Galvache 4, 28033 Madrid, Spain
}

Correspondence should be addressed to Miguel Ángel Sanjuán; masanjuan@ieca.es

Received 12 January 2017; Revised 25 May 2017; Accepted 21 June 2017; Published 30 July 2017

Academic Editor: Giorgio Pia

Copyright (c) 2017 Cristina Argiz et al. This is an open access article distributed under the Creative Commons Attribution License, which permits unrestricted use, distribution, and reproduction in any medium, provided the original work is properly cited.

Because of industrialization growth, the amount of coal power plant wastes has increased very rapidly. Particularly, the disposal of coal bottom ash (CBA) is becoming an increasing concern for many countries because of the increasing volume generated, the costs of operating landfill sites, and its potential hazardous effects. Therefore, new applications of coal bottom ash (CBA) have become an interesting alternative to disposal. For instance, it could be used as a Portland cement constituent leading to more sustainable cement production by lowering energy consumption and raw material extracted from quarries. Coal fly and bottom ashes are formed together in the same boiler; however, the size and shape of these ashes are very different, and hence their effect on the chemical composition as well as on the mineralogical phases must be studied. Coal bottom ash was ground. Later, both ashes were compared from a physical, mechanical, and chemical point of view to evaluate the potential use of coal bottom ash as a new Portland cement constituent. Both ashes, produced by the same electrical power plant, generally present similar chemical composition and compressive strength and contribute to the refill of mortar capillary pores with the reaction products leading to a redistribution of the pore size.

\section{Introduction}

For electrical power generation by coal combustion to become sustainable, the reuse of coal combustion by-products such as bottom ash is necessary. But also, coal bottom ash (CBA) used as a Portland cement constituent will help in more sustainable cement production by lowering energy and raw material consumption. The European Union is promoting the improvement of resource efficiency and the reduction of the climate and environmental impacts, through enhancing waste reuse and recycling according to the waste hierarchy of the European Waste Framework Directive 2008/98/EC [1].

Currently, the total worldwide cement production is over 4.0 billion tonnes [2] which provides more than $6 \%$ of total global warming $\mathrm{CO}_{2}$ emissions. Currently, climatic change is one of the biggest challenges facing the world, and some industrial by-products such as coal fly ash, silica fume, and granulated blast furnace slag are being used as Portland cement constituents because this means a decrease of $\mathrm{CO}_{2}$ emissions. Likewise, their disposal as industrial residues in landfill is avoided. Therefore, blended cements are part of the sustainable development strategy of the cement industry and also they allow improving the properties of the final concrete. It is well known that concretes made of blended cements have good durability $[3,4]$. This fact will promote the demand for such kind of cement.

Industrial by-products usage reduces energy consumption during cement production, lowers $\mathrm{CO}_{2}$ emissions, and, finally, makes waste management more efficient. Then, new Portland cement constituents as ground coal bottom ash should be assessed and evaluated for use in the mentioned blended cements.

Bottom ash and fly ash are by-products formed in coalfired electrical power stations. Fly ash applications in mortars and concretes were presented elsewhere [5]. Mainly, fly ash is used as a Portland cement constituent, as a supplementary cementitious material (SCM) in concrete, replacing fine aggregates, as a subbase material in motorways, and in other useful ways $[5,6]$. On the other hand, coal bottom ash is used as sand in concretes, among other minor applications, or disposed of in landfills [7]. Park [8] has recently found that the characteristics of coal ash reuse are determined more 
TABLE 1: Chemical composition of raw materials: coal bottom ash (BA), coal fly ash (FA), and cement (\%).

\begin{tabular}{lcccccccccccc}
\hline Oxides & $\mathrm{SiO}_{2}$ & $\mathrm{Al}_{2} \mathrm{O}_{3}$ & $\mathrm{Fe}_{2} \mathrm{O}_{3}$ & $\mathrm{CaO}$ & $\mathrm{MgO}$ & $\mathrm{SO}_{3}$ & $\mathrm{~K}_{2} \mathrm{O}$ & $\mathrm{Ti}_{2} \mathrm{O}_{5}$ & $\mathrm{P}_{2} \mathrm{O}_{5}$ & $\mathrm{LOI}$ & $\mathrm{IR}^{*}$ & $\mathrm{Cl}^{-}$ \\
\hline Cement & 20.9 & 4.3 & 3.5 & 62.7 & 1.9 & 3.4 & 0.9 & 0.25 & 0.10 & 3.7 & 1.04 & 0.023 \\
FA & 50.5 & 28.9 & 4.7 & 5.0 & 1.8 & 0.21 & 0.8 & 1.56 & 0.76 & 3.6 & 71.3 & 0.000 \\
BA & 52.2 & 27.5 & 6.0 & 5.9 & 1.7 & 0.13 & 0.6 & 1.53 & 0.74 & 1.8 & 75.7 & 0.001 \\
\hline
\end{tabular}

* Insoluble residue determined by the $\mathrm{Na}_{2} \mathrm{CO}_{3}$ method (European standard $\mathrm{EN}$ 196-2:2013).

TABLE 2: Bottom ash (BA) with fly ash (FA) and cement (CEM I $42.5 \mathrm{~N}$ ) mixes.

\begin{tabular}{|c|c|c|c|c|c|c|c|}
\hline \multirow{2}{*}{ Cement mix } & \multirow{2}{*}{ Raw material } & \multicolumn{6}{|c|}{ Fly ash + bottom ash mix codification } \\
\hline & & $\alpha$ & $\beta$ & $\gamma$ & $\delta$ & $\lambda$ & $\Omega$ \\
\hline \multirow{3}{*}{ CEM I } & Fly ash & $0 \%$ & & & & & \\
\hline & Bottom ash & $0 \%$ & & & & & \\
\hline & Cement & $100 \%$ & & & & & \\
\hline \multirow{3}{*}{ CEM II/A-V } & Fly ash & & $10 \%$ & $9 \%$ & $8 \%$ & $5 \%$ & $0 \%$ \\
\hline & Bottom ash & & $0 \%$ & $1 \%$ & $2 \%$ & $5 \%$ & $10 \%$ \\
\hline & Cement & & $90 \%$ & $90 \%$ & $90 \%$ & $90 \%$ & $90 \%$ \\
\hline \multirow{3}{*}{ CEM II/B-V } & Fly ash & & $25 \%$ & $22,5 \%$ & $20 \%$ & $12,5 \%$ & $0 \%$ \\
\hline & Bottom ash & & $0 \%$ & $2,5 \%$ & $5 \%$ & $12,5 \%$ & $25 \%$ \\
\hline & Cement & & $75 \%$ & $75 \%$ & $75 \%$ & $75 \%$ & $75 \%$ \\
\hline \multirow{3}{*}{ CEM IV/A (V) } & Fly ash & & $35 \%$ & $31,5 \%$ & $28 \%$ & $17,5 \%$ & $0 \%$ \\
\hline & Bottom ash & & $0 \%$ & $3,5 \%$ & $7 \%$ & $17,5 \%$ & $35 \%$ \\
\hline & Cement & & $65 \%$ & $65 \%$ & $65 \%$ & $65 \%$ & $65 \%$ \\
\hline
\end{tabular}

by business decision-making behaviors than by market or institutional factors.

Coal fly ash pozzolanicity is a property resulting from its content of silica, alumina, and iron oxide, but also fly ash presents a filler effect in mortars and concretes. In some concretes, the filler effect can be more significant than the pozzolanic one [9].

According to Kiattikomol et al. [10], the most important parameter affecting the fly ash pozzolanicity is its fineness, even more than its chemical composition. The fly ash fineness effect on compressive strength has been previously reported [10-12]. Ground fly ash mortars showed a higher early strength than mortars produced with coarse ashes. In consequence, a ground bottom ash, similar to a ground fly ash, can help to get denser mortars and concretes.

In this paper, physical, chemical, and mechanical properties of the coal bottom ash mortars are compared to those of coal fly ash mortars for assessing the use of ground bottom ash as a new cement constituent.

\section{Method and Materials}

The influence of ground coal bottom ash on the properties of the mortars was examined by means of testing mechanical and physical properties of ground coal bottom ash in comparison with coal fly ash mortars.

2.1. Materials. Cement type CEM I $42.5 \mathrm{~N}$ according to the EN 197-1:2011 [13] and coal bottom ash and coal fly ash collected from the same coal-fired power plant were used as the main constituents in the proposed new cement mixes.
Table 1 shows the chemical characteristics of the coal bottom ash, coal fly ash, and cement.

The specific surface Blaine of the cement was $4,050 \mathrm{~m}^{2} / \mathrm{kg}$; fineness of the collected coal fly ash was $3,976 \mathrm{~m}^{2} / \mathrm{kg}$. The coal bottom ash was ground in a ball mill up to a Blaine fineness of $3,463 \mathrm{~m}^{2} / \mathrm{kg}$, similar to that of the Portland cement (5-8\% residue on $45 \mu \mathrm{m}$ sieve).

Several coal fly and ground coal bottom ashes were mixed in the laboratory using a powder mixer. The different ground coal bottom ash and coal fly ash mixes are shown in Table 2.

Finally, the reference cement, CEM I $42.5 \mathrm{~N}$, was partially replaced by the ash mixes mentioned in Table 2 . The mix proportion of the laboratory-made cements in the research was chosen for fly ash blended cements according to EN 197-1:2011 [13]. That is to say, laboratory blended cements with similar compositions to the CEM II/A-V, CEM II/B-V, and CEM IV/A (V) standardized cements according to the European standard EN 197-1:2011 were made.

Tested mortars were made with a cement/sand ratio of 1:3 and a water : cement ratio of 0.5. Distilled water was used. Standard sand was also employed according to the European standard EN 196-1:2016 [14]. The mixing, moulding, and curing procedures are detailed also in the European standard EN 196-1:2016.

2.2. Testing. Compressive strength tests were performed according to the European standard EN 196-1:2016 [14]. Setting times and soundness were determined according to the European standard EN 196-3:2005 + A1:2008 [15]. Also, mercury intrusion porosimetry (MIP) tests were performed to determine the pore size distribution (PSD). 


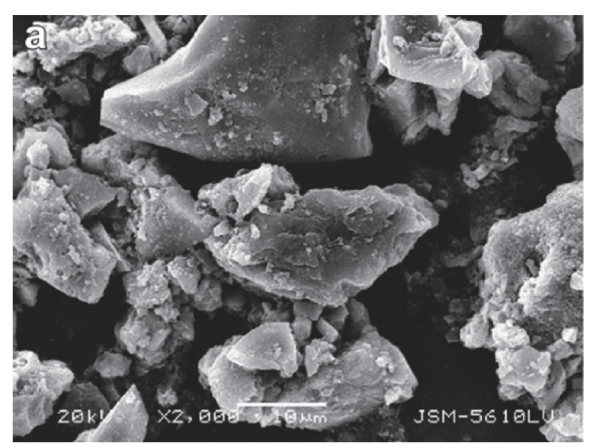

(a)

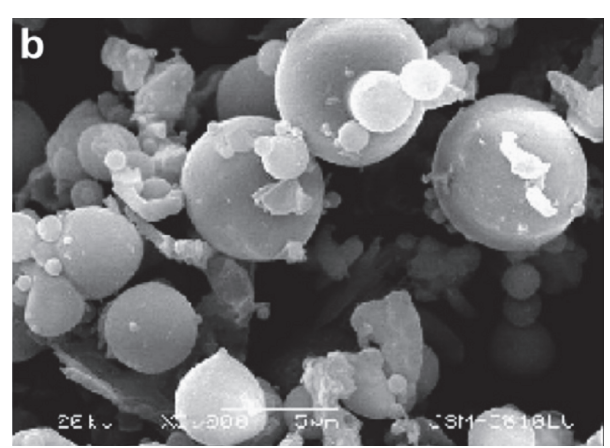

(b)

Figure 1: SEM images of coal bottom ash (a) and coal fly ash (b).

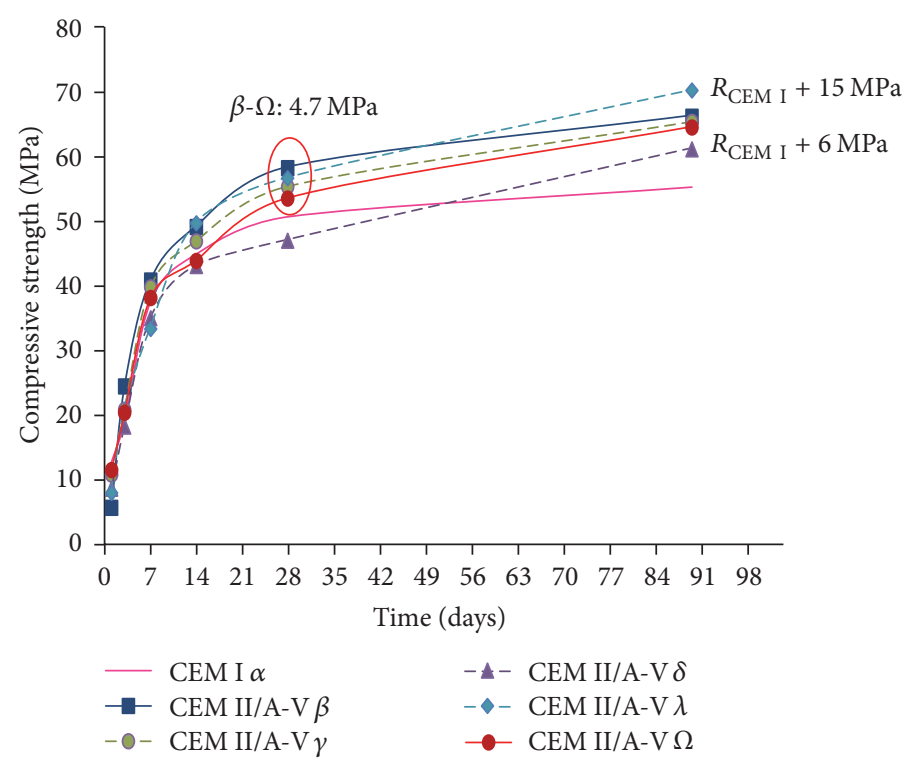

FIGURE 2: CEM II/A-V compressive strength (MPa).

\section{Results and Discussions}

Results of physical, chemical, and mechanical properties of the coal bottom ash mortars in comparison to CEM I and coal fly ash mortars are discussed below.

3.1. Characteristics of Coal Bottom Ash (BA) and Coal Fly Ash (FA). The chemical compositions in the coal bottom ash belong to the $\mathrm{CaO}-\mathrm{SiO}_{2}-\mathrm{Al}_{2} \mathrm{O}_{3}-\mathrm{Fe}_{2} \mathrm{O}_{3}$ system (Table 1 ). Therefore, they belong to the family of the common supplementary cementitious materials (SCM) used in cement-based products. Coal bottom ash is formed in the same incinerator as coal fly ash. Therefore, a similar chemical composition was expected in both.

Coal bottom ash is denser than coal fly ash, contributing to the low loss on ignition (LOI) in the first one (Table 1). Such loss on ignition is mainly due to unburned coal particles.

Figure 1 illustrates SEM photographs of the ground coal bottom ash and coal fly ash. The surface of coal bottom ash has irregular particles, whereas coal fly ash is characterized by a more uniform distribution of spherical grains with a fairly smooth surface. The spherical shape is probably produced because the particles of fly ash usually experience higher temperatures and such spherical shape is formed due to the shrinkage of the liquid phase.

3.2. Results of Mechanical Strength. Compressive strength of mortars measured at $1,3,7,14,28$, and 90 days is presented in Figures 2, 3, and 4 for CEM II/A-V, CEM II/B-V, and CEM IV/A (V), respectively.

As shown in Figures 2, 3, and 4, the compressive strength of the mortar specimens at 28 days decreased gradually with increasing of coal bottom ash or fly bottom ash or mixes of them.

The mortars' early strength decreases when the ground coal bottom or fly ash content is over $10 \%$. As expected, the coal bottom ash activity as well as the coal fly ash cement activity is lower at early ages. Thus, both ashes delay the cement hydration as the content is increased.

CEM IV/A (V), with 35\% replacement of cement by coal ash in mortars, showed worse strength evolution than 


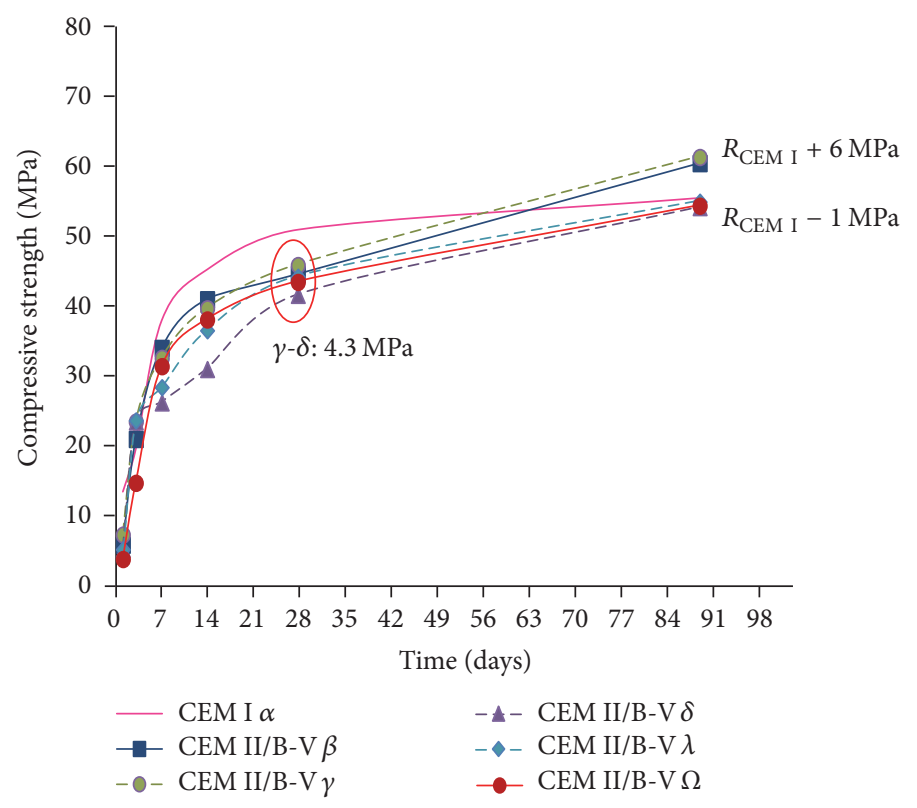

FIGURE 3: CEM II/B-V compressive strength ( $\mathrm{MPa})$.

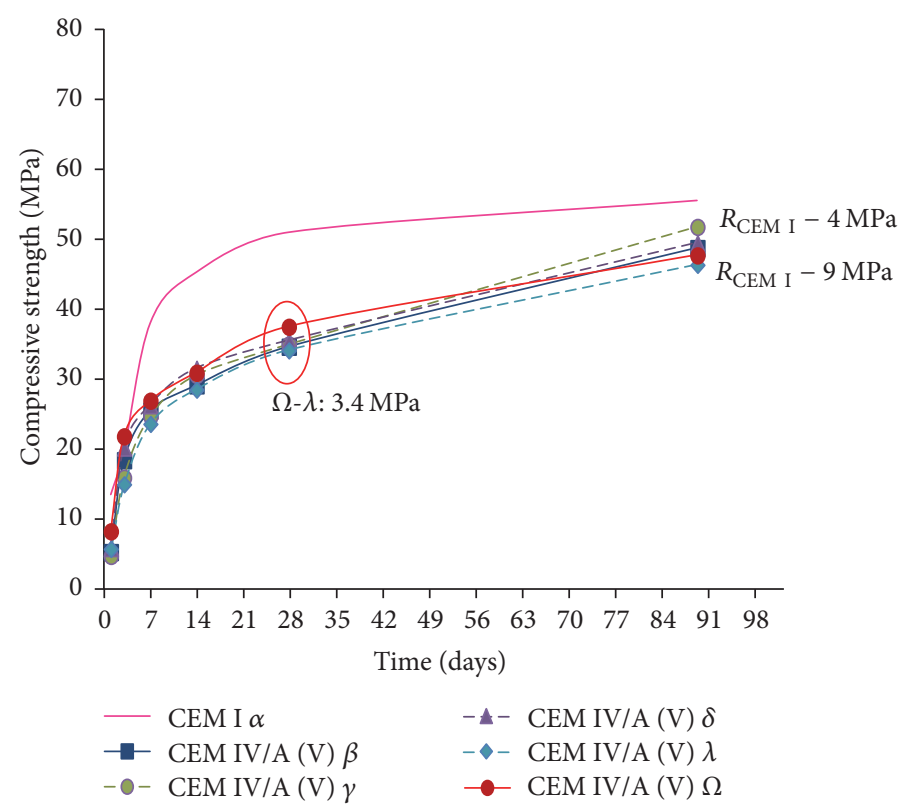

Figure 4: CEM IV/A (V) compressive strength (MPa).

CEM II/A-V and CEM II/B-V mortars. Its twenty-eight-day compressive strength is slightly over $32.5 \mathrm{MPa}$, which is the lower limit for the 32.5 strength class established in the European standard EN 197-1:2011 [13]. This fact suggests that the upper limit for coal bottom ash replacement of cement to ensure the compressive strength performance is around $35 \%$. In particular, the 28-day compressive strength of CEM IV/A (V) $\Omega$, with coal bottom ash, is higher than CEM IV/A (V) $\beta$, with coal fly ash (Figure 4 ). In consequence, it is evident that coal bottom and fly ashes have a certain pozzolanic activity, but a lower reactivity than the reference cement CEM I 45.5 $\mathrm{N}$, and, therefore, both ashes lead to retardation of cement hydration. From Figure 4, it can be said that the differences between coal fly ash and coal bottom ash are not significant.

3.3. Mercury Intrusion Porosimetry (MIP). Figure 5 shows the mercury intrusion porosimetry (MIP) results at seven days, while Figure 6 shows such results at 28 days. Both ashes contribute to the refill of the mortar capillary pores with the pozzolanic reaction products leading to a redistribution of the pore size. After 28 days of curing, the mortar with ashes showed flatter PSD curves than at seven days. This particular pore size distribution contributes to a good 


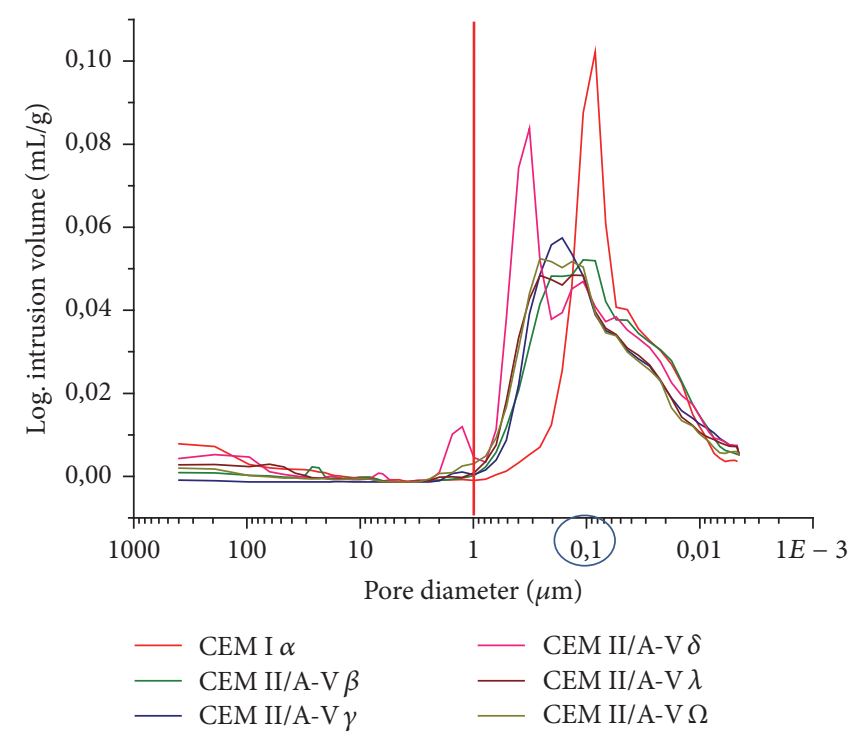

Figure 5: Mercury intrusion porosimetry (MIP) results at seven days.

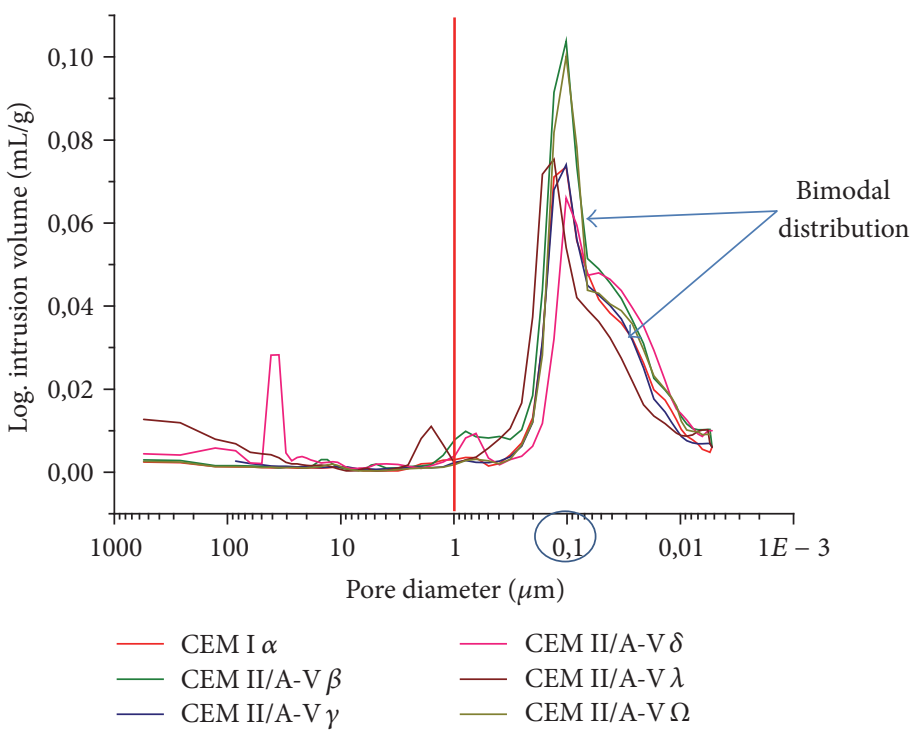

Figure 6: Mercury intrusion porosimetry (MIP) results at 28 days.

durable performance of the blended mortars. The use of coal bottom ash or coal fly ash does not make any difference.

3.4. Water Demand for Normal Consistency and Setting Time. The water demand for normal consistency in CEM II/A-V and CEM II/B-V cement pastes is lower than that of the reference cement CEM I $42.5 \mathrm{~N}$ (Figure 7). Comparing the blended cement pastes, it can be observed that the water demand for normal consistency increases when the amount of ashes increases in the cement independently of the type of ash used (Figure 7). However, the incorporation of coal bottom ash in CEM IV/A (V) cement pastes increases the water demand for normal consistency. This effect increases with the amount of coal bottom ash in the cement pastes, that is, cement pastes from $\gamma$ to $\Omega$.

With regard to the initial and final setting times, generally, the more the ashes in the cement, the longer the setting times recorded. Setting times of CEM II/A-V cement pastes, with only $10 \%$ of ashes in the binder mix, are quite similar to those of the CEM I $42.5 \mathrm{~N}$. In CEM II/B-V cement pastes, the reduction of the setting times is clearer in comparison to the reference mortar (Figure 8), and CEM IV/A (V) cement pastes showed the longest setting times.

With relation to the type of coal ash employed, the bottom ash cements $(\Omega)$ evidenced shorter setting times than fly ash cements $(\beta)$ as shown in Figure 8. This could be due to the higher amount of cement hydration retarders in the coal fly ash such as $\mathrm{ZnO}, \mathrm{Pb}_{2} \mathrm{O}, \mathrm{Cu}_{2} \mathrm{O}$, and $\mathrm{Cd}_{2} \mathrm{O}$ [16]. 


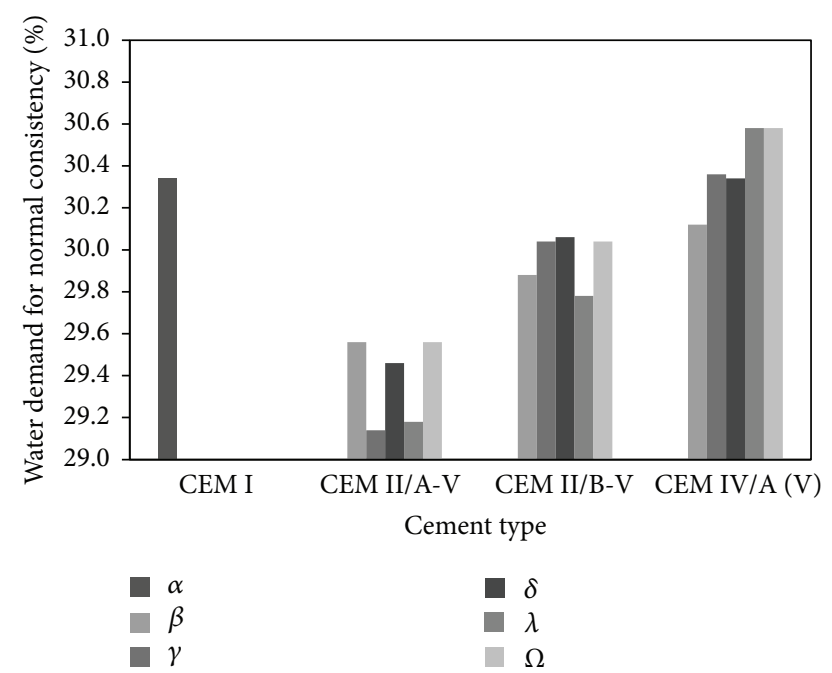

Figure 7: Water demand for normal consistency of the cement pastes.

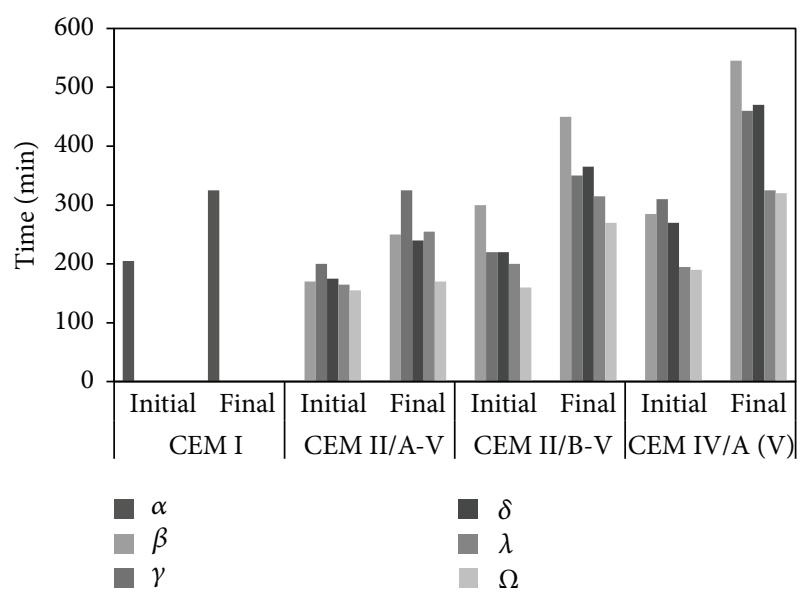

Figure 8: Setting time of the cement pastes.

3.5. Soundness. Soundness results go from 0.25 to $1.75 \mathrm{~mm}$. It is evident that the more the ashes used, the more the soundness found in the cement paste. Such effect increases from CEM II/A-V to CEM IV/A (V) cement paste. Also, when the amount of bottom ash increases in the cement paste (from $\beta$ to $\Omega$ ), its expansion gets longer (Figure 9).

\section{Conclusions}

Ground coal bottom ash and coal fly ash produced by the same electrical power plant were tested in order to investigate the possible application of the ground coal bottom ash in Portland cement production. The clinker/cement factor has a direct impact on $\mathrm{CO}_{2}$ emissions; in other words, the lower the clinker/cement ratio, the lesser the $\mathrm{CO}_{2}$ emissions. Then, one of the most viable approaches to reduce $\mathrm{CO}_{2}$ emissions is the study of the viability of new cement constituents as the ground coal bottom ash.

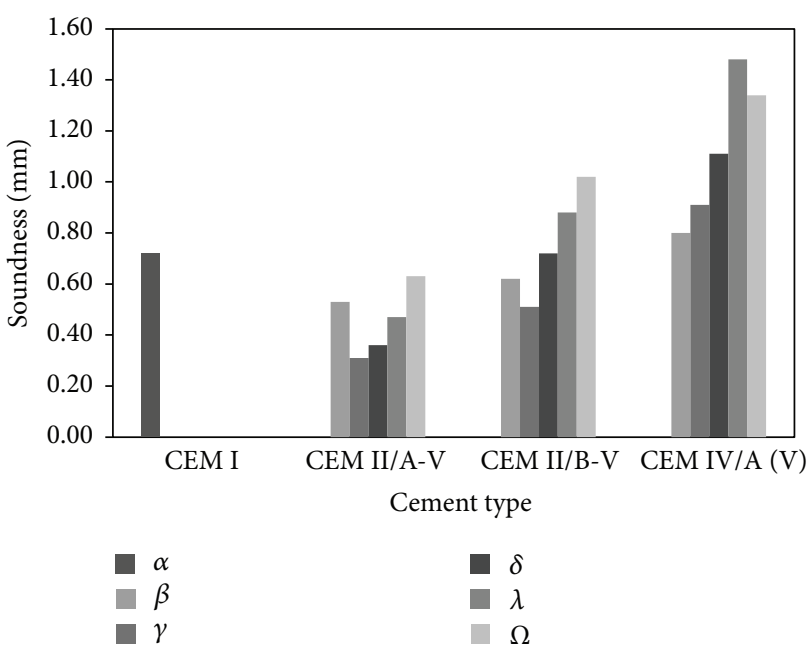

Figure 9: Soundness of the cement pastes.

Based on the presented analysis, the following conclusions can be drawn:

(i) Ground coal bottom ash and coal fly ash produced by the same electrical power plant present similar chemical composition. In particular, coal bottom ash has a lower loss on ignition than coal fly ash. This parameter is mainly attributed to unburned coal particles.

(ii) Ground coal bottom ash mortars, in general, showed compressive strength performances similar to those of coal fly ash cement-based materials. Activity is lower at early ages; therefore, the compressive strength of the mortar specimens at 28 days decreased gradually with the increasing of ground coal bottom ash or fly bottom ash or mixes of them.

(iii) From the mercury intrusion porosimetry (MIP), it can be concluded that both ashes contribute to the refill of the mortar capillary pores with the pozzolanic reaction products leading to a redistribution of the pore size. This PSD curve is flatter at 28 days than at seven days of curing.

(iv) The water demand for normal consistency increases when the amount of ashes increases in the cement independently of the type of ash used.

Consequently, ground coal bottom ash alone or mixed with coal fly ash is suitable to be used in cement production as a new main component in the Portland cement standards.

\section{Conflicts of Interest}

The authors declare that they have no conflicts of interest.

\section{Acknowledgments}

The authors wish to acknowledge IECA for financial support (AU 23-10 Contract: "Durable Physicochemical Characterization of Cement-Based Materials with Industrial ByProducts"). 


\section{References}

[1] European Parliament, European Waste Framework Directive, 2008.

[2] “CEMBUREAU, the European Cement Association," Activity Report, 2015.

[3] M. A. Sanjuán and C. Argiz, "Cement standardization: standardization evolution with regard to the industrial by-product use as cement constituent," Cemento \& Concreto de Iberoamérica y el Caribe, vol. 2, pp. 90-99, 2015.

[4] M. I. Khan, "Evaluation of non-destructive testing of high strength concrete incorporating supplementary cementitious composites," Resources, Conservation and Recycling, vol. 61, pp. 125-129, 2012.

[5] C. Argiz, E. Menéndez, A. Moragues, and M. A. Sanjuán, "Fly ash characteristics of Spanish coal-fired power plants," Afinidad, vol. 72, pp. 269-277, 2015.

[6] L. D. Poulikakos, C. Papadaskalopoulou, B. Hofko et al., "Harvesting the unexplored potential of european waste materials for road construction," Resources, Conservation and Recycling, vol. 116, pp. 32-44, 2017.

[7] M. Singh and R. Siddique, "Effect of coal bottom ash as partial replacement of sand on properties of concrete," Resources, Conservation and Recycling, vol. 72, pp. 20-32, 2013.

[8] J. Y. Park, "Assessing determinants of industrial waste reuse: The case of coal ash in the United States," Resources, Conservation and Recycling, vol. 92, pp. 116-127, 2014.

[9] M. Á. Sanjuán, C. Argiz, J. C. Gálvez, and A. Moragues, "Effect of silica fume fineness on the improvement of Portland cement strength performance," Construction and Building Materials, vol. 96, pp. 55-64, 2015.

[10] K. Kiattikomol, C. Jaturapitakkul, S. Songpiriyakij, and S. Chutubtim, "A study of ground coarse fly ashes with different finenesses from various sources as pozzolanic materials," Cement and Concrete Composites, vol. 23, no. 4-5, pp. 335-343, 2001.

[11] P. Chindaprasirt, S. Homwuttiwong, and V. Sirivivatnanon, "Influence of fly ash fineness on strength, drying shrinkage and sulfate resistance of blended cement mortar," Cement and Concrete Research, vol. 34, no. 7, pp. 1087-1092, 2004.

[12] B. Felekoğlu, S. Türkel, and H. Kalyoncu, "Optimization of fineness to maximize the strength activity of high-calcium ground fly ash-Portland cement composites," Construction and Building Materials, vol. 23, no. 5, pp. 2053-2061, 2009.

[13] M. A. Sanjuán and C. Argiz, "La nueva norma europea de especificaciones de cementos comunes UNE-EN 197-1:2011," Materiales de Construcción, vol. 62, no. 307, pp. 425-430, 2012.

[14] CEN European Committee for Standardization, Methods of Testing of Cement: Part 1. Determination of Strength, The European Standard EN 196-1, CEN, Brussels, Belgium, 2016.

[15] CEN European Committee for Standardization, Methods of Testing of Cement: Part 3. Determination of Setting Time and Soundness. The European Standard EN 196-3, CEN, Brussels, Belgium, 2011.

[16] M. Murat and F. Sorrentino, "Effect of large additions of Cd, $\mathrm{Pb}, \mathrm{Cr}, \mathrm{Zn}$, to cement raw meal on the composition and the properties of the clinker and the cement," Cement and Concrete Research, vol. 26, no. 3, pp. 377-385, 1996. 

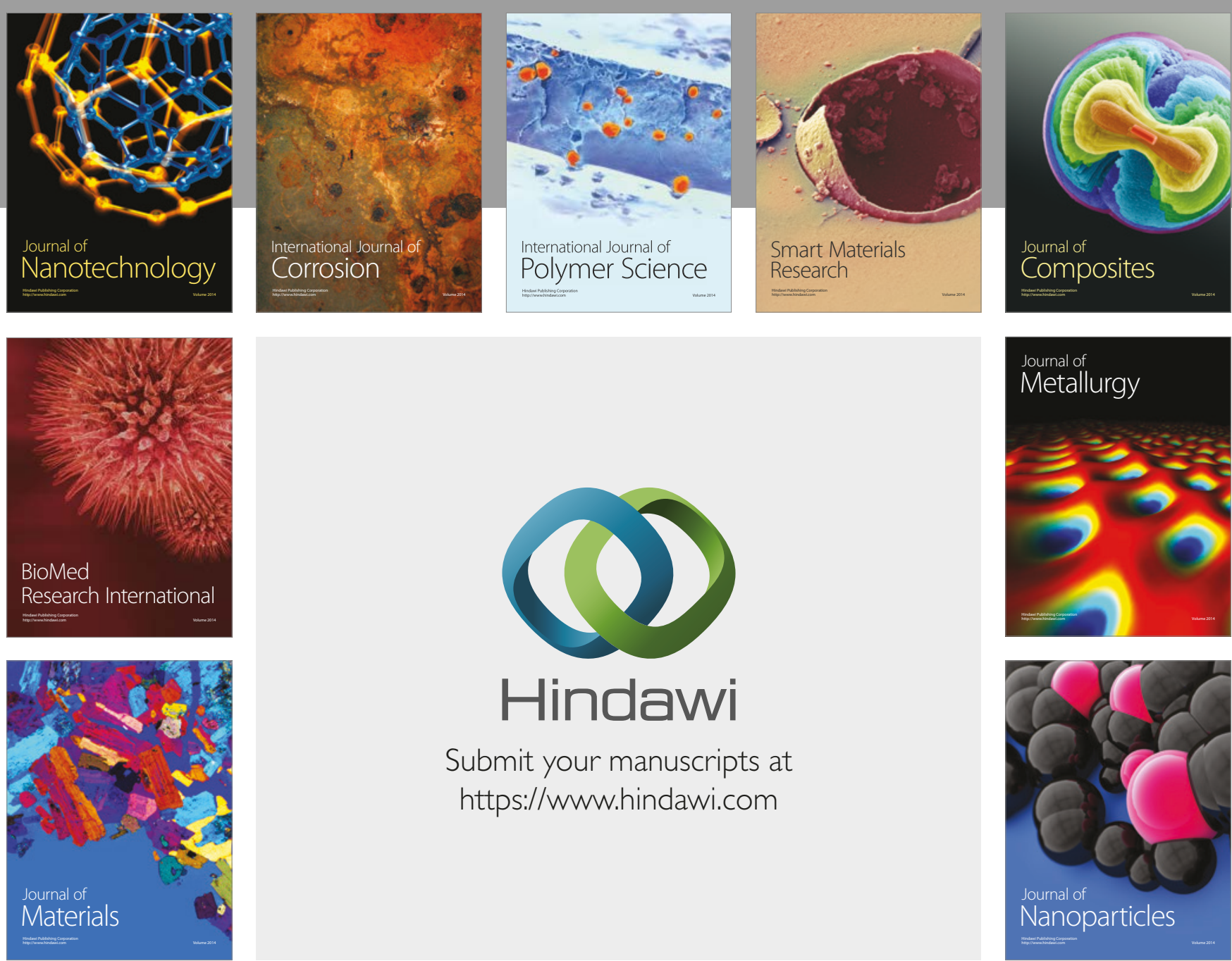

\section{Hindawi}

Submit your manuscripts at

https://www.hindawi.com
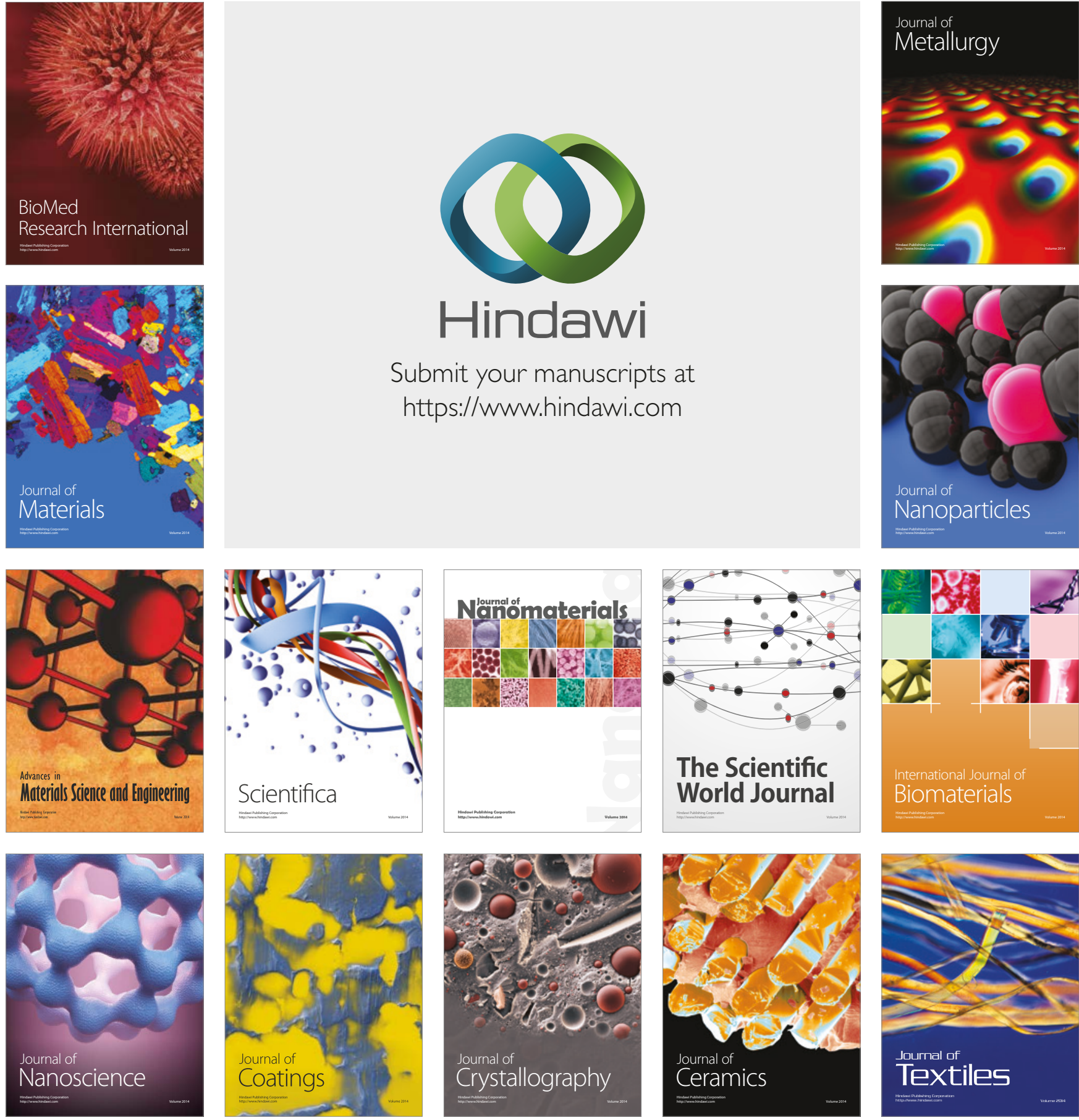

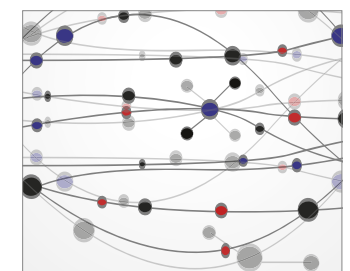

The Scientific World Journal
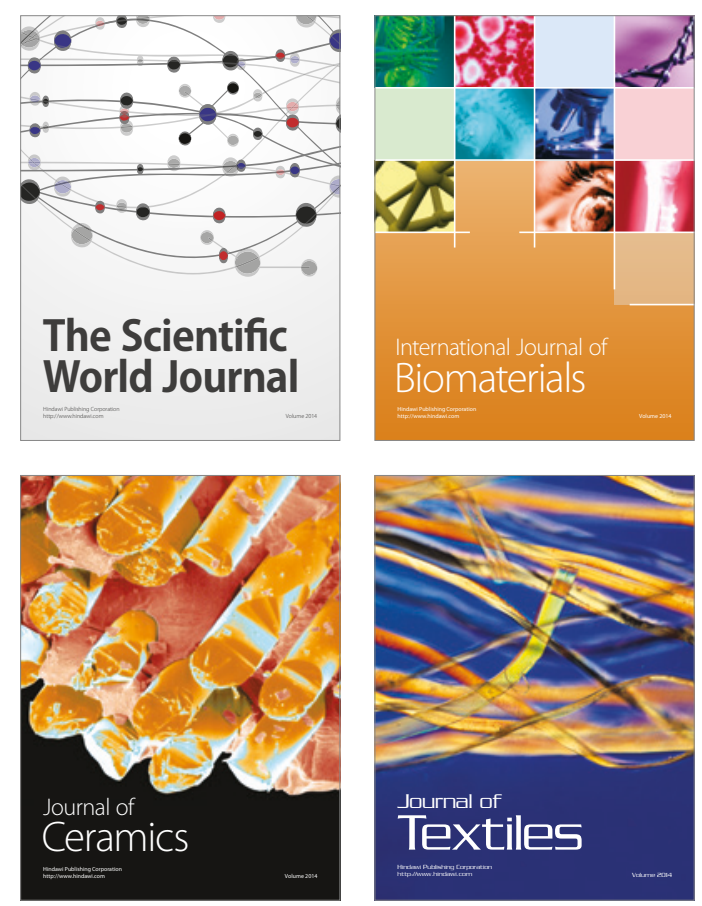